\title{
Interview with Michael Cronin
}

\section{Michael Cronin and Clíona Ní Ríordáin}

\section{(2) OpenEdition}

\section{Journals}

\section{Electronic version}

URL: http://journals.openedition.org/etudesirlandaises/1939

DOI: 10.4000/etudesirlandaises.1939

ISSN: 2259-8863

\section{Publisher}

Presses universitaires de Rennes

Printed version

Date of publication: 30 December 2010

Number of pages: $25-33$

ISBN: 978-2-7535-1246-7

ISSN: 0183-973X

\section{Electronic reference}

Michael Cronin and Clíona Ní Ríordáin, «Interview with Michael Cronin », Études irlandaises [Online], 35-2 | 2010, Online since 30 December 2012, connection on 19 April 2019. URL : http:// journals.openedition.org/etudesirlandaises/1939; DOI : 10.4000/etudesirlandaises.1939

This text was automatically generated on 19 April 2019.

(c) Presses universitaires de Rennes 


\title{
Interview with Michael Cronin
}

\author{
Michael Cronin and Clíona Ní Ríordáin
}

1 Michael Cronin (Ph. D. Trinity College, Dublin). Author of the ground-breaking, Translating Ireland , (Routledge 1996) Michael Cronin is the foremost translation scholar working in Ireland today. Cronin established the cultural review Graph with Peter Sirr and Barra Ó Séaghdha in 1986 and was involved in the setting up of the Irish Translators Association and the creation of Ireland Literature Exchange, the body responsible for funding the translation of Irish literature. He took up a teaching position in Dublin City University in the late 1980s and was Dean of the Faculty of Humanities and Social Sciences at DCU from 2000-2004 and Director of the Centre for Translation and Textual Studies from 2001-2008. He has published extensively in the areas of translation studies, tourism, travel writing, language and politics. He is currently co-editor of The Irish Review. Among the awards and honours bestowed on him are Membership of the Royal Irish Academy, Honorary Membership of the Irish Translators and Interpreters Association, Officier de l'Ordre des Palmes Académiques. He is the recipient of the President's Research Award in the Humanities and Social Sciences, the CATS Vinay-Darbelnet Prize for the best work published in translation studies and the Prix du Québec. He has held visiting Professorships in the Université de Moncton (New Brunswick, Canada) and the Universidad Ricardo Palma (Lima, Peru).

2 - In your book Translating Ireland published in $1996^{1}$ you commented on the relative absence of reflection in the area of translation studies has the situation evolved or developed since then?

- There have been changes since I wrote the book in 1996. I'm thinking of the work that has been done by scholars like Maria Tymoczko ${ }^{2}$, Kathleen Shields ${ }^{3}$, and the collection of essays that came out a year ago from Queen's University Press Aistriú Éireann ${ }^{4}$, looking at translation from Irish. There have been a number of monographs published on translators into and out of Irish. So to some extent, from the point of view of scholarship, and the fact that there are students in various Irish universities working on the question of translation, there has been progress there. What still strikes me however is that one of the most significant features of Irish life, linguistically, culturally and politically is this 
question of translation, the quite remarkable translation of the country from one language and one culture to another. Yet, when you read many Irish works of history, of cultural criticism, of social commentary, it still remains a very marginal fact; it's still by and large not commented on. Despite the fact that translation, it seems to me, is an extremely interesting way of looking at very fundamental shifts and changes in Irish life, politics and writing, in terms of the languages that are spoken on the island.

- You mention the languages that are spoken on the island; with the opening up of the country to the most recent European accession states, the fact is that when you walk around the streets of Ireland today Ireland is increasingly multi-lingual and multi-cultural. Do you think that has made a difference to our appreciation of translation and the necessity for it? Or have people remained deaf to it because of the dominant position of English within the world?

- I think the fundamental shift that has happened in Ireland with respect to the arrival of migrants from elsewhere speaking different languages is the shift from what I call extrinsic alterity to intrinsic alterity. What I mean by this is that before people used to think of translation and questions of contact with foreign languages as something to do with when you left the country. When you went elsewhere, you met other people and spoke different languages. You had to, whether you liked it or not, engage in some form of translation. The notion was that difference and alterity were elsewhere. What has happened, not just in Ireland but in many other countries, is the rise of intrinsic alterity, where a lot of quite radical language difference is present in the corner shop, the house next door, the person sitting beside you in the lecture theatre. This is what Stuart Hall has called "vernacular cosmopolitanism", a kind of cosmopolitanism of the everyday and I think it has become an important feature of contemporary Irish life. The development has two consequences. One is a pragmatic consequence, which is that with the arrival of people from many different parts of the world there is a necessity in the health service, in education, in the legal system for translating and interpreting services to be made available. In other words, there is the emergence of a pragmatic need to deal with linguistic difference. I think there is another difference which is working its way slightly more slowly through the system which is that this linguistic shift tends to relativise the pre-existing translation or language space in Ireland. Whereas before there was very much the idea, in matters of linguistic difference, that when we talked of questions of translation we looked at the English-Irish language pair and fairly often this involved a kind of zero sum game between the two languages. What happens when other languages enter into the picture is that they relativise the position of English and Irish. If you take one example, a North Inner City school, St Mary's which is just off Dorset Street in Dublin city centre, the children in primary school there are speaking upwards of thirty languages, and one of those languages is Irish. But for the child who is speaking Irish, whereas before he or she would have stood out as anomalous, as different, as strange, now with 29 other languages being spoken, Irish is just another language being spoken, one language among many others. The multilingual reality of the city is beginning to relativise the bilingual question which often surrounded or haunted language debates in Ireland. There is another development that affects the nature of multilingualism and migration and it is to do with the creation of transnational language communities in the country. I think when we talk about anybody being located in a particular place, they, in a sense, bi-locate. One space they occupy is the material, physical space where a person can speak one or several languages but people now also occupy a virtual space, on the Internet, whether they're Skyping, emailing, texting and so on. You can be physically 
based in Dublin but spend an hour or two Skyping every evening to your sister in Romania, or your brother in Shanghai, or your uncle in Kinshasa. So there is a sense in which the translation space of the city has two dimensions to it. There is the physical dimension of vernacular cosmopolitanism and increasingly, it seems to me, the networked virtual translation dimension located in telecommunications/ informatics networks.

4 - It's interesting that you should raise the issue of technology. I want to talk to you about technology and translation and in particular machine aided translation. For instance, if you want to use Google, you can do so as Gaeilge and it's one of a number of languages available. Similarly, with your mobile phone the language that information appears in can be Irish or Romanian or a variety of other languages that you can choose from. Do you think that this technological reality, can also have impact as well on multilingualism and the ability to translate?

- I think this has an effect in a number of different ways. In the first place it's a consequence of globalisation. Responses to globalisation happen in two ways: centripetally and centrifugally. The centripetal response is to be found in a typical Google interface, where for example, you have a text written in English "You're lucky today" and you have the literal translation in another language, say Irish, "Tá an t-ádh ort inniu". What this does is to spread a kind of standard Anglophone syntax through these different technologies, so although the messages are translated into other languages, the basic thrust is centripetal, standardising and homogenising. The centrifugal, which is driven by a search for identity in global settings, leads to the demand for technologies and interfaces to be made available in different languages. I think we need to contrast the surface diversity of language substitution with content-driven diversity involving language difference that is facilitated by particular kinds of technologies. In this context, for example, Skype which enables a transnational linguistic community to be constituted seems to me to be a lot more significant than say translating iPhone instructions into whatever languages are spoken by iPhone customers. In the past when Irish emigrants went to the United States the party organised for them was called an American Wake and the chances were that people would never actually see them again. Not only that, but the contact they had with people back home, was also quite limited. So for many Irish speakers when they went to the United States the ability to speak the language disappeared. This has radically changed now. Mother tongue maintenance is greatly strengthened because of these transnational networks in communications; we can see this happening in areas in Western Canada for example with Chinese speakers. A consequence of this development is that translation will be an inescapable fact of life because, with the strengthening of mother tongue maintenance, the encounter between different languages and cultures will become more acute and not less. I see that of course as a potentially creative encounter.

5 - To come back to the issue of thirty languages in a Dublin school, an example of language diversity which would seem to lead to the necessity for language planning as a result. What is the provision for translation services and translation policy in Ireland? How it has evolved? What impact it has had on the training and development of participants, in education, in third level colleges for example.

- Well to some extent if you look at the situation with regard to translation programmes the very first undergraduate translation programme was established in the National Institute for Higher Education Dublin, as it was at the time, in 1982. The first Master's programme was established in what had become DCU, in 1991 and those programmes 
were created very much in response to the translation needs of European Union membership and economic integration. More recently, the Masters programmes established in NUI Galway and in Queen's University Belfast concentrate mainly on English-Irish translation and are related to the translation needs resulting from the implementation of the Official Languages Act (2007). So to some extent the first group of translation programmes was established in response to the EU and the second group in response to the internal state requirements of the Official Languages Act. The third area of need, however, is the translation requirements of new migrant communities. There is no proper national language policy to deal with this. There is no coherent translating and interpreting policy. If you take for example the legal system, a contract was awarded to a company, Lionbridge, to provide interpreting in the courts and the company receives substantial income from the Irish State to provide these interpreting services. There is absolutely no requirement that these interpreters be properly trained or that they have demonstrable proficiency in any of these languages they purport to master. In recent times, there has been a catalogue of incidents where the interpreters were manifestly unable or unwilling to perform as professionals. The situation is one of a high degree of disorganisation and a marked absence of regulation. Many existing practices are highly unethical, such as having young children interpreting for their parents in maternity hospitals. Ireland is not unique in this respect. The situation in many parts of Europe is not much better but the Irish case is all the more disappointing in that one would have thought that a country which has been bilingual since its inception would display a fair degree of sensitivity to language and translation issues. I think this brings us on to another issue which is the fact that translation was very often not dealt with in Ireland, not spoken about, because it was a kind of psychic wound. In other words, the very dramatic shift from one language to the other, the translation of a people, if you like, involved, it seems to me, a great deal of psychological damage, a psychic wounding. People just did not want to mention it, rather like alcoholism in a family setting, indicative of something that was there but that you didn't want to talk about. The nervousness, hesitancy, or reluctance around questions to do with language difference in the Irish case is to do in my view with this intense repression of the translation fact.

6 - The repression of the translation fact can also be seen, perhaps, in the campaign of certain newspapers; a number of very virulent articles have been written in certain newspapers in Ireland with regard to the expense of translation as a result of the Official Languages Act. Basically, translation is seen as unnecessary. English is seen as the language of the world and we should get on with it.

- The virulence of the arguments and the articles, the venom that you find, is completely out of proportion to their initial cause. The sums spent on translation are paltry when compared to the monies being used to shore up the banking system and the 22 billion euro and counting that has been invested by the tax-payer in the Anglo-Irish Bank. I think that what you are dealing with, in psychoanalytic terms, is a kind of symptom, where the response is radically out of proportion to the actual cause. The wound runs very deep and produces these kinds of excessive, vituperative reactions. The simple fact is that, by and large, despite the work of a number of scholars that I mentioned earlier, translation is still a largely unreported, unacknowledged cultural phenomenon in Ireland.

$7 \quad$ - In the preface to Aistriú Éireann, you talk about translation within an Irish context as being regarded as failure, failure of the revival movement.

- Yes, well I think that was one of the reasons why translation was simply not dealt with 
in Irish-language circles for decades after the revival. Translation was not talked about or when it was, it was generally in highly disparaging terms. Many of the writers who went to work as translators, such as Máirtín ó Cadhain or Seosamh ó Grianna, were very dismissive of the activity of translation. In Irish departments [in Universities] very little academic attention was devoted to the study of translation, despite the fact that translation was an omnipresent daily fact of the lives of Irish Gaelic speakers. I think that that the taboo came both from the fact that one was speaking a language that was affected by the process of translation and to have to translate was to admit that Irish had not become the dominant vernacular of the country. So, on the one hand there was intense antipathy to anything being translated because it was felt that it was anglicising the Irish language and a legitimate concern was expressed that excessively literal translation from English was damaging its specificity. On the other, there was the sense that if you had to translate from Irish into English or indeed put English alongside Irish this was to admit that the revival project had failed. The utopian myth of Gaelic monolingualism could not admit the translation fact. One of the most damaging consequences of this hostility or indifference was a lack of sociolinguistic realism. If people had been much more aware of the translation fact, then it would have been easier to take more appropriate measures to safeguard, protect and allow for the flourishing of the language, so there was kind of a socio-linguistic deficit. There was also an historical deficit in that the long tradition of translation for example in Irish was ignored for many years despite the fact that Irish often benefited from the contact with other languages through translation.

- A number of publishing houses in Ireland are concerned with the work of translation. New Island books commissioned a series of books from well known English language Irish writers and translated them into Irish. There is also a movement which aims to make contemporary Irish language literature available to an Anglophone public as well. This emerged after the publication of Dermot Bolger's The Bright Wave: An Tonn Gheal in 1986. Somebody like Louis de Paor, for example, has made a conscious decision to publish his poems first in Irish and to leave a gap or a space before bringing them out in an English language version. Other poets have adopted the strategy of self-translation. What seems to be at stake here is the issue of voice, and the tension between the majority language and the minority language. Louis de Paor has talked about translation smothering the original voice and the danger of the minority language being smothered.

- When this movement started in the 1980's with the collection from Raven Arts Press, The Bright Wave: An Tonn Gheal, there was a very real problem for Irish language poets at the time which was that of recognition. They really felt an acute sense of complete invisibility in their own country and elsewhere and one could say that one of the success stories of translation was the way in which it has given a visibility and a presence to Irish language poets like Nuala Ní Dhomhnaill, Louis de Paor, Gabriel Rosenstock and so on. That is the positive side to the story. The negatives, however, relate mainly to the primacy of poetic and linguistic voice. Particularly in the case of self translation the question that needs to be asked is on an island where English is so much the dominant presence and language, is the danger that it is the translation which becomes the original? When we talk about the original copy, the source text and the target text; the target text is the ultimate source text because English is the primary poetic voice. And there is a sense in some cases that even when the poet is writing in Irish, what they're doing is self translating from English and then producing this self-translation into English which in fact is the original text. It's rather like a post-modernist party piece but I think 
that it's a development that is also to be found in Scotland. A great number of poets and writers in Scots Gaelic self-translate and many Scots Gaelic writers have been quite critical of this for the same reasons that in a situation of acute linguistic vulnerability this translation fact can undermine the specificity and otherness of the minority language. This is the most potentially negative or damaging aspect of this phenomenon.

- I recall meeting an English language playwright in Paris who was aware that his play was going to be translated. "The idea of the translation," he said "I had that at the back of my head and I was thinking about it as I was writing". Critics talk about translation and contact between languages as a source of creativity. Can it also be, in that instance, if you're thinking about the translatability that it restrains people's creativity as opposed to giving free reign to something more unbridled?

- Absolutely, translation like any other human phenomenon is multiple and contains within it genuinely creative and progressive forces but it also contains within it forces that are limiting and disabling. In translation studies we talk about translation laws which are not really laws in the strictly scientific sense since trying to prove them is profoundly difficult but they are generally observable tendencies in translated texts. One of these 'laws' is explicitation, the tendency to spell things out for the reader. There seems to be a tendency when people are translating to want to explain at the same time and not just to write from one language to the other but in many cases to explain and to simplify. The danger is that sense of explication and the simplification can lead to the potential for universal banality. We could say that what characterises particular kinds of Hollywood film productions, what characterises the spread of fast food outlets or Starbucks coffee shops throughout the globe is that they are somehow translatable places because they are simplified into a certain number of elements which can be exported to pretty much any place on the planet. So you get what the French philosopher François Julien calls the pseudo-universality of the familiar, of the homogenous. The perennial danger with a certain notion of translatability is that it invites an approach to language which you find in certain forms of technical writing where you have controlled languages with a restricted syntax and lexicon. The advantage with texts produced in these controlled languages then is that it is much, much easier to translate these texts into lots of different languages. Well that sense of a controlled language, a limited lexicon could spread to other areas as well such as literary expression, a notion that you leave out certain cultural references because it would be too difficult for the readers in the other language. Let's simplify, in other words, and make the message universally accessible. Underneath every successful MacDo is the fact of translatability and translatedness. This is the shadow side of translation.

10 - But on the plus side, I wonder if translation, as a veil or a layer we have to pass through before going on to something else, is not helpful. I'm thinking in particular of two sets of poems I've read recently, a book of poems Robert Welch has written in memory of his son, largely based on translations of Ovid's Tristia ${ }^{5}$ and the other the poems based on Rilke that Máire Mhac an tSaoi ${ }^{6}$ has written in memory of her husband Conor Cruise O'Brien. Does the extra layer that you have to dig through to get to the other side allow these poets to express their grief? Translation in that sense is enabling.

- I think of a very old archetype for translation which picks up on the translations you've mentioned, which is that of the voyage. If we think of this archetype, it generally involves the hero leaving his native land, the journeys outwards. There are all kinds of trials and tribulations and then he eventually returns to the land from which he's come, to his Ithaca. As he merges back into the community, of course, he becomes aware that he has 
been unsettled by that wandering and that on his return he is an unsettling presence. When Ulysses returns home a bloodbath ensues as he slaughters the suitors of Penelope and when the prodigal son returns home in the New Testament account he's a very unsettling presence. In Brian Friel's Translations, when Owen comes back to Ballybeg, he's the prodigious son because he can speak the King's English and Irish but he's also an unsettling presence because he speaks the language not only of the insiders but of the outsiders. So it seems to me that voyage which takes place when Bob Welch enters into dialogue with Latin or Máire Mhac an tSaoi engages with German, is a kind of voyage outwards. When you bring things back to 'home' language through translation, you're an unsettling presence. This is how people evolve and how wisdom is acquired. It is through trials and tribulations and the journey out that is the journey into the unknown. You bring those unknown things into the community in order to enrich the life of that community but it's not an easy process like any form of deep travel. And so its seems to me that there is a sense in which translation corresponds to a very profound almost archetypal need in humanity for the voyage outwards, which is accompanied by the return voyage and the recreation of the community from which the traveller has left.

Thank you.

\section{NOTES}

1. Michael Cronin. Translating Ireland. Translation, Languages, Culture. Cork, Cork University, Press, 1996.

2. Maria Tymoczko, The Irish "Ulysses", Berkeley, University of California Press, 1994; Translation in a Postcolonial Contex, Manchestert St. Jerome Publishing, 1999.

3. Kathleen Shields, Gained in Translation: Language, Poetry and Identity in Twentieth-Century Ireland, Oxford and Bern, Peter Lang, 2000.

4. Charlie Dillion and Ríona Ní Fhrighil, Aistriú Éireann, Belfast, Cló Ollscoil na Ríona, 2009.

5. Robert Welch, Constanza, Belfast, Lagan Press, 2009.

6. Máire Mhac an tSaoi, "In Memoriam Conor Cruise O'Brien", Irish Pages, Vol 5/1, p. 43-46.

\section{AUTHORS}

\section{CLÍONA NÍ RÍORDÁIN}

Conducted by Clíona Ní Ríordáin, Dublin, June 2010 